\title{
Alfarabi’s Conversion of Plato’s Republic
}

\author{
Mahmood N. Khoshnaw \\ College of Languages, Salahaddin University/Hawler, Erbil, Iraq \\ Email:mahmoodkhoshnaw@yahoo.com,.mh665508@ohio.edu
}

Received November $5^{\text {th }}, 2013$; revised December $15^{\text {th }}, 2013$; accepted January $2^{\text {nd }}, 2014$

\begin{abstract}
Copyright (c) 2014 Mahmood N. Khoshnaw. This is an open access article distributed under the Creative Commons Attribution License, which permits unrestricted use, distribution, and reproduction in any medium, provided the original work is properly cited. In accordance of the Creative Commons Attribution License all Copyrights (C) 2014 are reserved for SCIRP and the owner of the intellectual property Mahmood N. Khoshnaw. All Copyright (c) 2014 are guarded by law and by SCIRP as a guardian.
\end{abstract}

\begin{abstract}
It might not be very inspiring to do an introduction to Alfarabi’s (870-950 A.D.) philosophy and works through his On the Perfect State. This is because of the obvious dependence and extensive borrowing from Plato's Republic which might undermine the rich philosophy he presents in his other major and more known works. Besides, and similar to Plato, many of the philosophical views presented and raised in the On the Perfect State are detailed in his other works. Nonetheless, and as it will be shown below, he distinguished a number of his ideas from Plato and modelled them to suit his Islamic perspectives and audience. This article attempts to illustrate a number of Plato's ideas that Alfarabi has remodelled.
\end{abstract}

Keywords: Alfarabi; Plato; Republic; Perfect State

In the context of Islamic philosophy, Alfarabi's importance lies in the fact that he attempted to "naturalize the philosophical learning of the Christians with the Islam. Combining Aristotelian cosmology and psychology with Neoplatonic metaphysics and a curious political Platonism, he made a unique contribution of political thought of Islam” (Zimmerman, 1981: p. ix). Globally or at least in the context of other revealed religions, "a novel aspect of Alfarabi's thought is that it lays the philosophical foundation for political programs in the postclassical age, dominated by revealed religions" (Azadpur, 2003: p. 566). Leo Strauss considered Alfarabi "as a predecessor of Maimonides and as a representative of a kind of rationalism distinct from modern rationalism" (Colmo, 1992: p. 966). Strauss's view of knowledge of the best way of life to be "crucial to political philosophy” (Colmo, 1992: p. 966) might explain his lifelong interest in Alfarabi who in turn, inherited this from Plato. Especially that Alfarabi's On the Perfect State can be regarded as a "tool for learning about the human soul and the cosmos; in other words, that it teaches us how to live" (Bonelli, 2009: p. 43). Also understanding works of Alfarabi is key to understanding a number of philosophical issues raised by Plato, Aristotle, and Maimonides (Colmo, 1992). Strauss, for example, considers understanding Alfarabi's The Political Government as the only beginning to understand Maimonides philosophical background (Strauss, 1945).

Alfarabi's admiration and passion to Plato's philosophy is very evident. He pursued Plato's manner of dialogue and believed that Plato's philosophy and the platonic views to be the "true” philosophy (Strauss, 1945). A common ground they had for their "ideal" or "perfect" states is their hope "that a reasonable arrangement of human relations is possible" (Kabadayi, 2004: p. 238). They also shared the belief that "no such reasonable arrangement is possible unless the authentic conditions of men's place in nature and reality are studied” (Kabadayi,
2004: p. 238). Alfarabi also emphasises the important role of philosophers and follows Plato in making human happiness dependent on the existence of a philosopher king (Colmo, 1998). This philosopher king is also dominant in his other political writings (Colmo, 1998). This seems to be unorthodox and especially considering the suspicious views towards philosophy and philosophers in the conservative Muslim world of the time which further explains Alfarabi blending of philosophy and religion.

Yet, and given the new context, Alfarabi departs, develops or converts a number of Plato's arguments. One of these, which might be a principle argument for many later utopias, is universalism or the universality of the laws or opinions presented for the people of these utopias. Joshua Parens (1994) notes that Alfarabi's understanding of Plato contrasts the Western held view of him in this regards. Alfarabi "presents a Plato who denies moral universalism but acknowledges the possibility of some form of universalism, at least in the realm of knowledge” (p. 169). Parens, however, concludes that these laws and although particular have universal values, universally supported and people "must believe that their laws are the best as measured in accordance with some universal standard of justice” (p. 174).

The issue of universal laws whether intended by Plato or not is questionable. After all, Plato stresses the supremacy of Greek over the rest and indicated the possibility of duplication and extension of these "good" cities. In the case of Alfarabi however, we notice his efforts to make his opinions in line with orthodox religion (i.e. the majority), in which universality is essential to its thrive and domination. Alfarabi clearly describes his perceived ideal city to be "universal" and also its ideal ruler to have a universal element in him:

This is the sovereign over whom no other human being 


\section{N. KHOSHNAW}

has nay sovereignty whatsoever; he is the Imam; he is the first sovereign of the excellent city, he is the sovereign of the excellent nation, and the sovereign of the universal state (p. 247) ${ }^{1}$.

likewise In On the Perfect State, Alfarabi explains that knowledge of the good is not bound to any certain nation or religion, rather excellent cities can exist and simultaneously anywhere provided that people have the same excellent goals.

On the Perfect State, is written in narrative presentation unlike the dramatic structure of Plato. It opens with a description of the attributes of the "First Existent", or God. This is as Alfarabi wrote for a conservative society, and it was the custom of the books of the time to start with praising Allah (God) and His attributes. However, and most importantly, Alfarabi attempts to establish a linkage whenever occasion permits between the "First Existent" and other sections and components of the work. Alfarabi also attempts to highlight the importance of this knowledge. Similar to Augustine, who believed that "happiness is having knowledge of God. Farabi, too, sees it as a divine wisdom” (Bonelli, 2009: p. 60). For Alfarabi:

The first aim of knowledge was knowledge of God and his attributes, a knowledge which has a profound effect on the human being's moral conduct and helps him to find the way to the ultimate aim of his existence, while indirectly arousing the intellect so that it should achieve wisdom, which al-Farabi held to be the highest level of intellectual attainment permitted to human beings in this life. (al-Talbi, 1993: p. 356).

Plato's Republic also illustrates that the knowledge of god(s) and knowing their true attributes affect the manners of human beings and their image (gods) determines people's behaviour. It can be noted however, that Plato presents these attributes mainly and particularly to support his argument against poets who have distorted the image of gods and their attributes.

Alfarabi attributes certain qualities to the First Cause of the existence that are common to the context of revealed religions. Nevertheless, they echo the ones of Plato, like being "free of every kind of deficiency, whereas there must be in everything else some kind of deficiency... the highest kind of excellence... perfect... without being in need to any other thing...what is perfect in beauty is that apart from which no beauty of its species exist” (Alfarabi, p. 57). These can be easily compared to Plato's "gods are perfect in form and beauty" (Plato, p. 74) ${ }^{2}$.

Alfarabi, however, goes further in his description of the "First Cause" to include attributes that might not have been relevant or known to the pagan society of Plato. Alfarabi says that this First Cause "is neither matter nor is it at all sustained by a matter or a substratum; its existence is free of all matter and substratum... nor does it have form, because form can exist only in matter... likewise it has not derived its existence from something else prior to it, and even less so from inferior to it" (Alfarabi, 59). Such description was very common in the widespread Sophist schools of his time. Yet, Alfarabi still borrows many concepts and terminologies of which Plato uses in describing "the elements in mental conflict" (Plato, p. 139).

\footnotetext{
${ }^{1}$ All Quotations from Alfarabi's On the Perfect State are taken from the translated text of Richard Walzer, Great Books of the Islamic World, Inc, 1998, Oxford University Press.

${ }^{2}$ All Quotations from the Republic are taken from the translation of Desmond Lee, Penguin Books, second edition (London, 2003).
}

Alfarabi, discusses the faculties of the soul and body of humans. A human being, he says, consists of nutritive, perception, appetite, and rational faculties. These faculties arise consecutively. These faculties, again following Plato, consist of a ruling and subordinate parts (auxiliaries). Yet, Alfarabi replaces the heart with Plato's reason to rule over the faculty of the senses. When comes to male and female difference in respect to the capacities of these faculties, Alfarabi states that: "But in the case of faculty of sense, the faculty of representation and the faculty of reason male and female do not differ” (Alfarabi, 197). Alfarabi, however, is far more modest in the explanation of male and female differences/resemblance than Plato is.

Alfarabi highlights the importance of cities and societies, which is a product of humans' need to "gathering" to attain needs that cannot be obtained or met by people individually. These societies, "some of which are perfect, others imperfect" (Alfarabi, 229), represent individuals attempt to achieve perfection that correspond to faculties attempting to achieve the same. This perfection is to be distinguished from the attainment of happiness by citizens (as individual members or collectively) which Alfarabi comments on in a later part of On the Perfect State, again following Plato's method in the Republic. In words of Azadpur (2003), this perfect city or "the ideal political state":

is so organized that it brings the citizens as close as they can be to the condition of ethical excellence. Because Alfarabi lays the emphasis on the individual's struggle for excellence, the inquiry into the ideal state cannot be a political program per se; it is rather the project of bringing to light and motivating the achievement of a just (virtuous), soul (p. 567).

A central difference between Alfarabi and Plato is the role of the "perfect individual" or citizen in building the perfect city. For Plato, citizens have a minor role and their perfection is not of priority compared to the guardians or philosophers. While in Alfarabi, that perfection is sought for every citizen of the city or community as they all act as one organism. Alfarabi desires all the citizens to have a minimum knowledge of everything, while Plato is strict on the division of labour and ones dedication to the knowledge only related to his occupation and details the process of educating the guardians and philosophers.

Moreover, a single Ruler in Alfarabi substitutes Plato's ruling class of philosophers. Again, this can be attributed to the form of government of Alfarabi's time or the Caliphate system. It might be also argued, as it will be clearer in the later parts of the On the Perfect State, to a possible affiliation of Alfarabi to the Shiite religious group that believed in the "Imams" a direct descendent of the fourth Caliph. It was believed to have been twelve of them. In fact what supports this, beside the argument by a number of scholars (Bonelli, 2009), is his constant referral to this ruler as "Imam". To give further sanctity to the role of the Imam, Alfarabi' makes the organizing of the city more dependent on this Ruler than the philosopher of Plato's Republic:

In the same way the ruler of this city must come to be in the first instance, and will subsequently be the cause of the rise of the city and its parts and the causer of the presence of the voluntary habits of its parts and of their arrangement in the ranks proper to them; and when one part of out of order he provides it with the means to remove its disorder (pp. 235-237). 


\section{N. KHOSHNAW}

Besides, Alfarabi attributes the qualities of prophets to this ruler, which further obscures his character. The Leading scholar Muhsen Mahdi articulates "a distinction between prophecy and revelation" from an Islamic perspective which "helps a great deal in making sense of some of the obscurity in Alfarabi's texts" in this regards (cited in Azadpur, 2003: 567). The character of this Ruler is both "inborn" and acquired. Such habits, he continues "will develop in a man whose inborn nature is predisposed for it". Achieving perfection is also an aim of this person. The tasks of the Ruler also go beyond the philosopher of Plato. For Plato emphasizes supervision and guidance and distributed other duties (like fighting to the guardians). Here we see a man who is an orator, leader at war, and the imam (which also means the religious juristic). P. Crone (2004) argues "that Farabi's supreme ruler is similar to the ideas found in the writings concerning the Hellenistic kingships" (cited in Bonelli, 2009: p. 153). Alfarabi also says that "nobody has any sovereignty whatsoever" over this man, which exempts him from any accountability and grant him a sacred status and immunity:

and God almighty grants him Revelation through the mediation of the Active Intellect, so that the emanation from God Almighty to the Active Intellect is passed on to his Passive Intellect through the mediation of the Acquired Intellect, and then to the faculty of representation (p. 245).

Again and as in Plato, Alfarabi admits that "it is difficult to find all these qualities united in one man" (Alfarabi, 249). The difference is that Alfarabi stresses that only one man at a time might have these qualities, while in Plato it could be multiple ones, although still rare. In brief, Alfarabi makes the philosopher-king or the Imam the corner stone of the city. Al-Talbi (1993) stresses that Alfarabi's core philosophy of the unity of society and state can:

be achieved by unity of thought, wisdom and religion, each of these being the foundations of the community's government, which should be the same as the unity and order found in the universe. Indeed, al-Farabi often compares the order and unity of the city to that of the universe (p. 357).

It is worth noticing that the "perishing" of the perfect city in Alfarabi's view is directly linked to the absence of the "Imam", while in the Republic it originates from the loss of the guardians' moral qualities (Plato, 277).

A number of subdivisions of the ignorant city are listed by Alfaraby: the city of necessity; the city of meanness; the city of depravity; the city of honour; the city of power; and the "democratic" city. Alfarabi's Arabic term for democracy is "collective" or "grouped" in which "the aim of its people is to be free, each of them doing what he wishes without restraining his passions in the least” (Alfarabi, 257). Although, the democratic city is listed among the ignorant ones, but Alfarabi singles it out as the best of the worst. Muhammad Ali Khalidi (2003) argues that this different stand on democracy, and "his departure from Plato in this context is significant and points to some revealing differences between the two philosophers" (p. 379). Since Alfarabi's "view of democracy also seems negative in important respects, he breaks significantly with Plato by saying that of all the imperfect cities, this is the most admirable and happy city" (Khalidi, 2003: p. 384). Nonetheless, Plato too, although described democracy "as the plight of philosophy", explained that most people "judge it to be the best form of soci- ety” (Plato, 293).

Khalidi (2003) proposes three suggestions to explain Alfarabi view of the democratic city:

First, the democratic city contains virtuous individuals and groups. Alfarabi recognizes communities of virtuenot neighborhoods or clan-based... second, perhaps as a result of the first reason, the democratic city is most easily transformable into a virtuous city. Though Alfarabi is not explicit concerning the process of transformation, his emphasis on the presence of virtuous communities suggests that these groups might play a role in converting the democratic city into a virtuous city. On this point, he explicitly breaks with Plato, who seems to hold that the process of establishing a virtuous city requires a more radical rupture with the status quo. Finally, Alfarabi's favorable attitude to democracy can also be explained by the fact that it accords well with the universalist character of official Islamic doctrine (p. 393).

Alfarabi states that in all human societies two forces exist "one for war and defence, and one for establishing peaceful relations" (Alfarabi, p. 313). Here, in another depart from Plato, he grants a balanced role to the army class over the working classes. In general and unlike Plato, he does not grant immunity to the class of fighters or make them superior to other classes.

Alfarabi then discusses the views of the cities "which miss the right path". This terminology indicates that these cities have chosen to swerve away from established religious orthodoxies. The use of such religious terminologies is Alfarabi's attempt to blend philosophy with religion. The views of these people include dogmas about the relationship between the soul and body, which controls which, which is the source of desire, etc. The way Alfarabi presents these views go in line with the Sophists schools of his day. The rest of the dialogue centre around similar arguments of which Alfarabi's premier philosophy is seen. The importance of soul is stressed by both Plato and Alfarabi, who thought that "an ordered soul is possible only in an ordered society; besides, such an ordered society banks on the disciplined reading of the order of the universe by a group of disciplined minds and disinterested hearts” (Kabadayi, 2004: p. 238). However, the debate and arguments Alfarabi makes about the soul was central and more relevant, and more novel, to his audience than the more physical and material oriented audience of Plato. Besides the full title of On the Perfect State is On the Opinion of the People of the Perfect State which indicates the importance and centrality of people's opinions and views in such city. Bonelli argues that Alfarabi's On the Perfect State "should be interpreted predominantly as a text that reveals the paths to happiness instead of the purely political work that it is commonly understood to be” (Bonelli, 2009: p. 62). Again, such aim is more esteemed to Alfarabi's society of monotheists than the pagan one of Plato.

\section{REFERENCES}

Al-Farabi (1998). On the Perfect State (R. Walzer, Ed. \& Trans.) New York: Oxford University Press, Kazi Publications.

Al-Talbi, A. (1993). AL-FARABI. Prospects: Quarterly review of comparative education, 1, 353-372.

Colmo, C. (1992). Theory and Practice: Alfarabi's Plato Revisited. The American Political Science Review, 86, 966-976.

http://dx.doi.org/10.2307/1964348 


\section{N. KHOSHNAW}

(1998). Alfarabi on the Prudence of Founders. The Review of Politics, 60, 719-741. http://dx.doi.org/10.1017/S0034670500050865

Parens, J. (1994). Multiculturalism and the problem of particularism. American Political Science Review, 88, 169-181. http://dx.doi.org/10.2307/2944889

Kabadayi, T. (2004). The Perfect State in Plato and Al-Farabi. AKÜ SOSYAL BILIMLER DERGISII, 2, 237-248.

Strauss, L. (1945). Farabi’s Plato. American Academy for Jewish Research, Louis Ginzberg, Jubilee Volume, 357-393.

Azadpur, M. (2003). Review of the Book Alfarabi and the Foundation of Islamic Political Philosophy by Muhsin S. Mahdi. Medieval Academy of America Review, 78, 566-568.
Khalidi, M. A. (2003). Alfarabi on the Democratic City. British Journal for the History of Philosophy, 11, 379-394.

http://dx.doi.org/10.1080/0960878032000119637

Bonelli, M. (2009). Farabi's Virtuous City and the Plotinian World Soul: A New Reading of Farabi's Mabadi' Ara' Ahl Al-Madina AlFadila. (Unpublished doctoral dissertation). Montreal: The Institute of Islamic Studies, McGill University.

Plato (2003). The Republic (2nd ed., D. Lee, Ed. \& Trans.). New York, NY: Penguin Books.

Zimmerman, F. W. (1981). Al-Farabi's Commentary and Short Treatise on Aristotle's De Interpretations. London: Oxford University Press. 